\title{
Fraud Risk Factor Of The Fraud Triangle Assessing The Likelihood Of Fraudulent Financial Reporting
}

\author{
Yung-I Lou, Nan Hua University, Chiayi, Taiwan \\ Ming-Long Wang, National Cheng Kung University, Tainan, Taiwan
}

\begin{abstract}
This research examines risk factors of the fraud triangle, core of all fraud auditing standards, for assessing likelihood of fraudulent financial reporting. Significant variables, including analyst's forecast error, debt ratio, directors' and supervisors' stock pledged ratio, percentage of sales related party transaction, number of historical restatements, and number of auditor switch, belong to pressure/incentive, opportunity and attitude/rationalization. Results indicate fraudulent reporting positively correlated to one of the following conditions: more financial pressure of a firm or supervisor of a firm, higher percentage of complex transactions of a firm, more questionable integrity of a firm's managers, or more deterioration in relation between a firm and its auditor. A simple logistic model based on examples of fraud risk factors of ISA 240 and SAS 99 gauges the likelihood of fraudulent financial reporting and can benefit practitioners.
\end{abstract}

Keywords: Risk Factors, Fraudulent Financial Statements, Fraud Triangle, ISA 240, SAS 99

\section{INTRODUCTION}

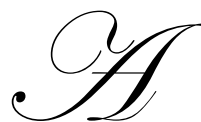

large increase in the number of financial frauds reported and subsequent business failures have led to concerns about legitimacy of corporate financial statements. These concerns have led to new auditing standards and regulations targeting the need for investors, regulators and auditors to concentrate on preventing and detecting such fraud. In 1988, the American Institute of Certified Public Accountants (AICPA) issued a Statement on Auditing Standards (SAS) 53 entitled The Auditor's Responsibility to Detect and Report Errors and Irregularities, which holds the auditor responsible for detecting errors and irregularities materially impacting financial statements. Yet Moyes and Hasan (1996) argued that negligible attention was given to auditors' qualifications in detecting fraudulent financial reporting. Then SAS 82 entitled Consideration of Fraud in a Financial Statement Audit was implemented in 1997 to assist auditors in detecting financial statement fraud in practice. SAS 82 also provided more explicit guidance on how auditors could achieve fraud detecting by looking at high-risk areas and categories. SAS 82 was superseded in 2002 by SAS 99 entitled Consideration of Fraud in a Financial Statement Audit to expand procedures to detect fraud. Ramos (2003) argued that the new standard (SAS 99) aimed to auditors' consideration of fraud incorporated fully into audit processes from the outset. Also in 2002, the International Auditing and Assurance Standards Board (IAASB) of the International Federation of Accountants (IFAC) issued International Standards on Auditing (ISA) 240 entitled The Auditors' Responsibility to Consider Fraud in an Audit of Financial Statements. Following ISA 240, the Auditing Standards Board of Taiwan issued a Statement on Auditing Standards (TSAS) $43^{1}$ entitled The Auditor's Responsibility to Consider Fraud in an Audit of Financial Statements in 2006.

Illustrative fraud risk factors of these fraud standards (SAS 99, ISA 240, TSAS 43) were based on the fraud triangle proposed in 1953 by D. R. Cressey in Other People's Money: A Study in the Social Psychology of

1 From 2002, ISA 240 was revised for several times. The majority of TSAS 43 was adopted from the ISA 240 implemented on Dec. 15, 2004. 
Embezzlement. Interviewing persons convicted of embezzlement, Cressy categorized conditions in fraudulent financial activities into pressure/incentive, opportunity, and attitude/rationalization. Input from forensic and academic experts consistently showed that evaluation of information about fraud was enhanced when considered in such a context. Recent studies on risk assessment of fraudulent financial reporting have focused mainly on examining several potential fraud risk factors or red flags. Although red flag literature affords some insight into the likelihood of fraud, a list of related indicators involves a great deal of subjective judgment and nonpublic information available only to auditors or insiders of a firm (Persons, 1995). Investors and policymakers cannot access the red flag list to identify firms engaging in fraudulent reporting. Owusu-Ansah et al. (2002) criticized red flag questionnaires as rather general, subjective and difficult to apply in practice. Eining et al. (1997) found auditors using a checklist of risk factors performed no better risk assessment than unaided auditors. They demonstrated that auditors aided by a logit model achieved more accurate assessment than either checklist users or unaided auditors. The majority of researches in predicting fraud have employed data in the USA; the present study extends the issue to Taiwan's data on three purposed aspects. First, we identify objective proxy variables rating pressure/incentive, opportunity, and attitude/rationalization, based on prior study. Second, each part of the fraud triangle is separately probed. Thirdly, we concoct and test our model to predict fraudulent financial statements, which can potentially benefit not only auditors or insiders but also investors and policymakers.

Samples examined in the present study are obtained from Taiwan Economic Journal (TEJ), the Securities and Futures Investors Protection Center (TSFIPC) ${ }^{2}$, and Newspaper. We use one fraud firm to match five non-fraud firms. 97 fraud fs and matched 467 non-fraud firms are used to develop and test a logistic regression model for evaluation in the likelihood of fraudulent reporting. Results indicate fraudulent reporting positively correlated to one of the following conditions: more financial pressure of a firm or a firm supervisor, higher percentage of complex transactions of a firm, more questionable integrity of firm managers, or more deterioration in relation between a firm and its auditor. The results also provide a model for applicable proxy variable relating the fraud triangle to yield $86.5 \%$ accuracy classifications. Likewise, security supervisors can apply this model to identify firms for fraud investigation or monitoring. Moreover, through this model, investors can avoid fraud risk and be assisted in investment decisions. When auditors preliminary assess new client engagement, the model can also be applied to evaluation in the likelihood of fraudulent financial statement. The remaining sections of this paper are organized as follows. The next section discusses relevant fraud research. A subsequent section develops hypotheses and sample selection. Besides, empirical findings are reported and discussed. Finally, we present our conclusions.

\section{PRIOR RESEARCH}

During the past two decades, interests from academic scholars and practitioners in the field of fraudulent financial reporting have grown dramatically (Persons, 1995; Beasley, 1996; Bell and Carcello, 2000; Kaminski et al. 2004). Albrecht and Romney (1986) published the first empirical study offering usefulness of red flags to predict fraud. Later, AICPA-issued SAS 53 clarifies auditors' responsibility for detecting fraud in 1988, and a large body of research has focused on risk assessment of fraudulent financial reporting for examining potential fraud risk factors or red flags. Loebbecke, Eining, and Willingham (1989) formulated a predictive model based on outlining numerous risk factors of SAS No. 53. Further researches expanded the model of Loebbecke, Eining, and Willingham (1989) to list red flags (Bell et al., 1991; Bell and Carcello, 2000; Hansen et al. 1996; Apostolou et al., 2001; Nieschwietz et al., 2000; Wilks and Zimbelman, 2004). The majority of these empirical studies were performed by surveys targeting external or internal auditors with questionnaires, where fraud risk factors were included in SAS 53 or SAS 82. While red flag studies offer some intelligence about fraud, a questionnaire is criticized to be lengthy and subjective. Bell and Carcello (2000) used a large number of variables (47 factors plus all possible interactions) to predict. Albrecht and Romney (1986) cited 87 red flags in survey. Their data on most of these factors were unavailable to other researchers or other users, and it is difficult to perform red flags in empirical operation (Owusu-Ansah et al., 2002). Lack of management integrity has been cited as a red flag, and it has referred to

2 According to the law for securities and futures investors protection practiced as of Jan. 1, 2002, the Taiwanese Securities and Futures Investors Protection Center (TSFIPC) was established. TSFIPC provided assistance about consultation and complaint-filing for securities and futures investors. 
subjective judgment. Cottrell and Albrecht (1994) argued that red flags were neither predictive nor absolute. Pincus (1989) considered questionnaires having no definite impact on fraud risk assessment. Asare and Wright (2004) found that auditors who used a checklist structured by SAS 82 risk categories made less effective diagnosis of the fraud than those without a checklist.

Another group of studies has examined whether financial ratios (analytical procedures) were useful in identifying fraud. Calderon and Green (1994) published the first empirical fraud risk research by using publicly available information to construct fraud model. A wide range of analytical procedures was extensively applied and included both financial and operating data (Calderon and Green 1994; Blocher and Cooper, 1988; Blocher, 1992). Persons (1995) only employed financial ratio affecting likelihood of fraudulent financial reporting and indicated financial leverage, capital turnover, asset composition and firm size as significant factors in detecting fraud. Heiman-Hoffman et al. (1996) documented that attitude risk factors perceived by auditors were more important than opportunity or incentive risk factors. Kaminski et al. (2004) demonstrated the limited ability of financial ratios to detect fraud. Apostolou et al. (2001) surveyed internal and external auditors via using the fraud risk factors listed in SAS 82. They also found that management characteristics were crucial predictor of fraud. Obviously, a predictive model considering financial ratio alone is not enough. Hence, the present investigation examines risk factors based on the triangle to detect fraudulent reporting.

Though AICPA outlined numerous fraud risk factors in SAS 53 and SAS 82, only SAS 99 categorized these factors according to the fraud triangle theory (Heiman-Hoffman et al., 1996; Wilks and Zimbelman, 2004). Wilks and Zimbelman (2004) argued the nontheoretical categorizations of risk factor in prior fraud auditing standards (SAS 53 and SAS 82) and in audit practice aids, suggesting sometimes impairment rather than improvement in auditors' fraud assessments. Just few studies on financial statement fraud are related to the fraud triangle. Wilks and Zimbelman (2004) examined whether separate assessments in management's attitude, opportunity, and incentive risks increase auditors' sensitivity to opportunity and incentive cues. Through questionnaire that listing 40 fraud-risk factors in the SAS 99, they found that when perceptions of management's attitude suggest low fraud risk, auditors who decompose fraud-risk assessments were more sensitive to opportunity and incentive cues than auditors who assess overall fraud risk. Although studies on the questionnaire method were ample in the literature, studies related to fraud triangle (Wilks and Zimbelman, 2004; Skousen and Wright, 2006) were limited. Skousen and Wright (2006) developed a fraud-prediction model that included risk factors related only to pressures and opportunities. However, attitude-risk factors were more important than opportunity or incentive risk factors (Heiman-Hoffman et al., 1996). We intend to construct a logical and simplifying model for fraud-risk assessment instead of lengthy and subjective fraud checklists, and provide a useful tool for practitioners.

\section{HYPOTHESES AND SAMPLE SELECTION}

\section{Hypotheses}

We may consider whether identified events or conditions provide useful information in identifying the risks of material misstatement due to fraud because fraud is usually concealed and difficult to detect. The fraud triangle indicates pressure/incentive to perpetrate fraud, opportunity to carry out the fraud, or attitude/rationalization to justify fraudulent action. Such events or conditions are referred to "fraud-risk factors." Although these fraud-risk factors do not necessarily imply the existence of fraud, they often are present in circumstance where fraud exists. The name of appendices in the three fraud-auditing standards (SAS 99, ISA 240, and TAS 34) is "Examples of Fraud-Risk Factors," which is relevant to misstatements arising from fraudulent financial reporting. Employing the examples cited in these auditing standards and referring to the prior literature, we develop several hypotheses and identify proxy variables representing various measures of pressure/incentive, opportunity, and attitude/rationalization.

\section{Pressure/Incentive}

Pressure/incentive results from a perceived pressure on managers or employees to commit fraud. A firm 
may hold incentives to manipulate earnings, when any of the following three conditions occurs. First, financial stability is threatened by economy and industry. Second, management is pressured for meeting expectations of third parties. Third, management or directors' personal financial situation is intimidated by the entity's financial performance. We propose the following hypothesis:

H1: When a firm sustains more financial pressure, we may identify more risks of material misstatements due to fraud.

A firm in a growth stage, it possesses the highest sale growth, the highest capital expenditure, the lowest dividend payout, and more requirement of outside capital fund (Black, 1998). Besides, if a firm lapses from growing trend, the stock price can be strong fluctuated (Barth et al., 1999). Stice (1991) found client growth to be positively associated with litigations and conjectures that high growth might be accompanied with ineffective internal control systems and misleading financial statements. Also, Bell and Carcello (2000) found that rapid company growth was a significant risk factor in likelihood of fraudulent reporting. To capture extreme growth levels, we follow Krishnan's (2005) measure by a dummy variable, high growth (HIGHGR), which is coded by 1 for growth rate on assets of a firm greater than that of industry median, and coded by 0 otherwise.

Degeorge et al. (1999) presented that hierarchy existed among the following three earnings thresholds: (1) avoiding negative earnings, (2) reporting increases in quarterly earnings, and (3) meeting analysts' earnings forecasts. Kasznik and McNichols (2002) found that abnormal annual returns were significantly large for firms meeting analyst's expectations after controlling for analysts' expectations of future earnings, and the markets also extraordinarily punished firms without meeting the expectations. This situation also imposed pressure on management to achieve earnings expectations. Lopez and Rees (2002) demonstrated that earnings multiple applied to unexpected earnings (i.e., realized earnings exceeding analysts' earnings forecasts) is significantly greater than that to negative unexpected earnings. Pressure imposed on management to meet analysts' earnings estimates is an important cause of fraudulence. Calderon and Green (1994) found that differences between financial analysts' forecasted earnings and reported earnings were positive correlated to likelihood of fraud. We use analyst's forecast error $(A F E)$ to measure one of the financial pressures on management. $A F E$ equals the value obtained by subtraction of company's realized earnings per share after restatement from the latest analysts' earnings forecasts of earnings per share in event year. The "event year" is defined by the year of financial statements with disclosure of fraudulent data. We predict positive relation between forecast error and fraud risk.

Hayn (1995), Lipe et al. (1998), and Collins et al. (1999) showed that the cross-sectional return (or price) earnings relation of firms reporting losses was much weaker than that of firms reporting profits. Hayn (1995) reported negative coefficients for regression of returns on earnings of firms posting losses over two or more consecutive years. We measure consecutive losses by (1) reporting losses over two years (LOSS) and (2) two or more successive years of negative cash flow from operation $(N C F O)$.

Dechow et al. (1996) argued that high leverage firms having debt covenants motivated the earnings manipulation. We use debt ratio (total debt to total assets; $L E V$ ) to measure leverage employed frequently in the extant literature as a proxy for closeness to covenants and associated with the existence and tightness of covenants (Duke and Hunt, 1990; Press and Weintrop, 1990). Leverage ratios are also likely to be proxy of demand for external financing motivation. We predicate that the relation between debt ratio and fraudulent reporting occurrence is positive.

H2: When directors and supervisors sustain more financial pressure connects with firm's earnings, management have more incentive to manipulate financial statements, resulting in fraud.

Since pledging for loans reduces personal fund demands, degree of personal leverage expanded by managerial stockholder increases risk of companies. When stock market collapses, managerial stockholders become motivated in maintaining stock price (collateral). If corporate governance is weak, corporate funds represent the easiest and fastest funding for stock-price support. Unfortunately, when stock markets continue collapsing, 
companies are trapped in financial difficulties (Lee and Yeh, 2004). We predicate that directors' and supervisors' stock-pledging rate (PLEDGE) increases fraud probability.

\section{Opportunities}

Opportunities result from circumstances that provide chances to commit fraud. Complicated transactions are accompanied with high inherent risk because of involvement in high degree of management judgment and subjectivity. Also, complicated transactions may present risks of material misstatement due to fraud because of susceptible to manipulation by management. We propose the following hypothesis:

H3: When higher percentage of complicated transactions emerges, a firm encounters greater probability of fraud.

This work examines two kinds of transactions. One is the impact of complex financial scheme on fraud. Enron executives devised complex financial arrangement to defraud Enron and its shareholders transacted off-the-books partnerships to make the company look far more profitable than it was (Bratton, 2002; Swartz and Watkins, 2003; Deakin and Konzelmann, 2004). Thus, we use equity investment ratio (INV\%) as a proxy of measure complex financial scheme. The other is related party transaction. In a case study, Young (2005) found that related party transactions were allegedly used to manipulate earnings, loot companies, and commit fraud. Since firms mainly operate by revenue recognition as window dressing for operating results (GAO, 2002; Palmrose et al., 2004), we select percentage of sales-related party transaction $(R P T \%)$ in the present model.

Effective internal control can maintain reliability of firms' financial statements and prevent fraud. Weak internal audit, even when management override controls, may increase the likelihood of material financial misstatement. We propose the following hypothesis:

H4: When a firm under weaker internal control environment, management has more opportunities to defraud financial statements.

Jensen (1993) argued for position separation of board chairman from chief executive officer (CEO)/president if a board is an effective monitoring device. Because a board chairman conducted board of director meetings and oversaw process of hiring and evaluation and compensation for the CEO, we evaluate how a board chairman occupying CEO/president position (CEO) impacts fraud occurrence.

La Porta et al. (1999) and Claessens et al. (2000) found that smaller ratio of cash flow rights to control rights represented higher tendency for controlling shareholders to expropriate minority wealth and lower firm valuation (La Porta et al., 2002). Lee and Yeh (2004) concluded that deviation in control away from cash flow rights was related to risk for financial distress. Poor corporate governance provided opportunities to controlling shareholders to transfer value from a firm into personal profit. In turn, reduction in corporate value led to a high probability of earnings manipulation. Hence, we study effects of deviation in control away from the cash flow rights (DEVR) in fraud risk, following method of La Porta et al. (1999, 2002). Definition of control right includes direct and indirect control rights. Direct control relies on voting rights of controlling shareholders, and indirect control is voting rights generated from shares held by entities that are in turn controlled by the controlling shareholders, as described in La Porta et al. (2002, p.1157):

A shareholder has an $x$ percent indirect control over firm A if: (1) she controls directly firm B which, in turn, directly controls $x$ percent of the votes in firm A; or (2) she controls directly firm $C$ which in turn controls firm $B$ (or a sequence of firms leading to firm B, each of which has control over the next one, i.e., they form a control chain) which, in turn, directly controls $x$ percent of the votes in firm A. A group of $n$ companies form a chain of control if each firm 1 through n-1 controls the consecutive firm. A firm in our sample has a controlling shareholder if the sum of her direct and indirect voting rights exceeds 10 percent. When two or more shareholders meet our criteria for control, we assign control to the shareholder with the largest (direct plus indirect) voting stake. 
Cash flow rights owned by controlling shareholders are computed as products of all equity stakes along the control chain. Deviation in control away from cash flow rights (DEVR) equals ratio of controlling shareholders' cash flow rights to control rights. We predict that in a firm with lower $D E V R$, management possibly expropriates minority wealth, yielding higher probability of fraud.

Besides, internal auditor is essential in support internal control function. Internal auditor is expected to play an effective role in deterrence, detection, and reporting of fraudulent reporting. Beasley et al. (2000) found that internal audit existence in fraud companies was less common than that of non-fraud companies. High internal auditor turnover reveals that organizational structure of a firm is unstable. Moreover, internal control components are deficient as a result of high turnover rates of internal auditor. We measure turnover frequency of internal auditor $(\triangle I N A U D)$, defined by number of internal auditor switch in the past three years (including event year). We predicate that high $\triangle I N A U D$ increases fraud probability.

\section{Attitude/Rationalization}

Attitude or character is what leads one or more individuals to rationally commit fraud. Management integrity (attitude) is a major determinant of financial statement quality. When manager integrity is queried, reliability of financial statement is doubtful. We propose the following hypothesis:

H5: When more queries about manager's integrity arise, a firm has greater probability of fraud.

While management attitude is not observable, we use a proxy, historical financial restatement times (RST) based on observed data, to capture management integrity. If a firm has higher frequency of financial restatement, reliability of financial statement is lower, and managers' integrity is queried. Historical financial restatement times are counted by number of earnings-affected restatement in the quarterly financial statement (including consolidated financial statement) during the two preceding years. For example, if the financial statement in 1997 is alleged fraud, number of restatement during the period 1995-1996 is measured. In addition, it includes voluntary and mandatory restatements.

Independent auditor is an important supervisor on financial reporting. Relationship between manager and auditor denotes the rationalization of firm management. Thus H6 is developed:

H6: When relationship between manager and auditor becomes worse, a firm encounters greater probability of fraud.

Sorenson et al. (1983) implied that a client could change auditors to reduce likelihood of detection of a financial statement fraud. Loebbecke et al. (1989) proffered that 36 percents of fraud in their sample were alleged in the initial two years of an auditor's tenure. Risk of audit failure and subsequent litigation in initial engagement are higher than those in subsequent years (Stice, 1991). Both Krishnan and Krishnan (1997) and Shu (2000) found that auditor resignation was positively associated with likelihood of litigation. With number of auditor switch in the event year $(\triangle C P A)$ as a proxy for rationalization, we predict that $\triangle C P A$ is positively correlated to the likelihood of fraud.

\section{Control Variables}

Larger firms usually have stronger internal control systems than smaller firms (O’Reilly et al. 1998). Strong correlation between firm size and financial fraud is demonstrated by previous paper (Bonner et al. 1998; Beasley et al. 1999). However, firm size is also controlled in our model, since our matching process is not exact. We predict a negative relation between firm size (SIZE) and fraudulent financial reporting. 


\section{Sample Selection And Data}

Our samples of financial statement fraud are limited to publicly traded firms because the present study focuses information available only in proxies and financial statements filed by the SEC. We glean samples from Taiwanese publicly traded firms, including Taiwan Stock Exchange (TSE) and Taiwan over-the-counter market (OTC). The majority of the samples are obtained from database named the Taiwan Economic Journal (TEJ). Identified fraud samples where a mandatory act address accounting and auditing irregularities was taken by the SEC during 1996-2006, are 123 firms. That a firm restates financial reporting exceeding two quarterly statements in one year is regarded as one sample. 52 samples belonging to three categories are excluded in the sample selection, as elaborated below. First, 37 samples are excluded because financial reporting of same firm were restated for the same reason in different years. Second, 12 firms of banks, securities, or insurance industry are removed. Third, three samples with incomplete information can not be counted. Other samples including 26 firms suited by investors, creditors, or regulators for fraudulent financial statements are obtained from the Securities and Futures Investors Protection Center (TSFIPC) and Newspaper. Thus, 97 firms with fraudulent financial statements are included in this paper. Table 1 (Panel A) lists the sample selection procedures.

Control firms are matched based on year, assets size, industry, and trade market (TSE or TOC) in the year preceding the event year (Beasley, 1996). Zmijewski (1984) argued that using a matched-pairs design derived existence of choice-based sample biases from "oversampling". Actual frequency rates of fraud firms in Taiwan are less than $20 \%$. We use one fraud firm to match five non-fraud firms, except when amount of company in industry is insufficient. Finally, 97 fraud firms matched 467 non-fraud firms in this study.

TABLE 1: Sample Composition

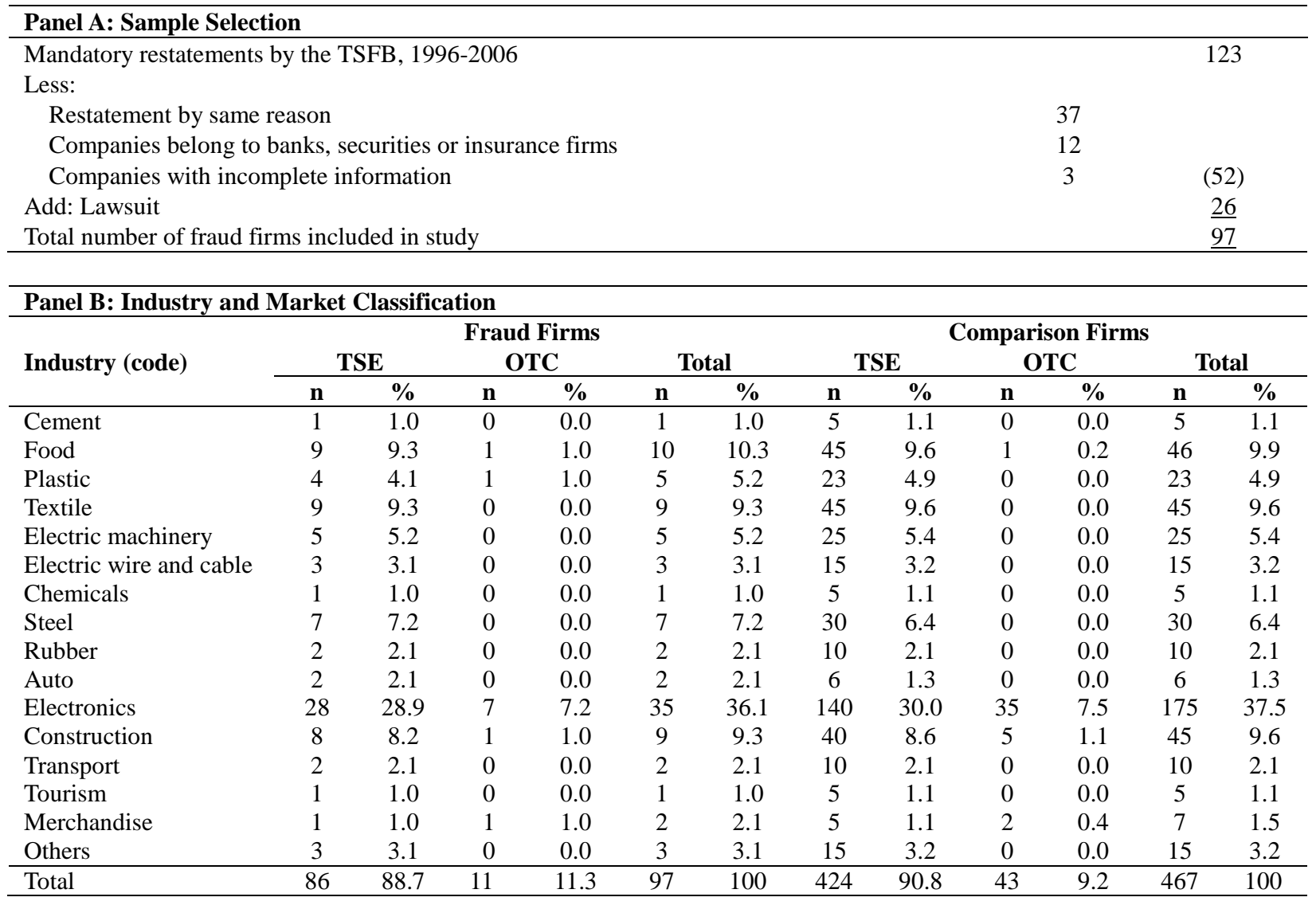


Panel B contains industry and market classification of samples. Most samples belong to electronics industry and TSE trade market. We use $\chi^{2}$ to test the impact of different industry and trade market on event occurrence. We find that phi value between industry of fraudulent firms and fraudulent financial occurrence is 0.028 ( $p$-value $=1.00)$. The phi value between fraudulent firm's trading market and event occurrence is -0.027 ( $p$-value $=0.52$ ). Impact of different industry and trade market on fraudulent financial occurrence is not statistically significant.

\section{RESULTS}

\section{Descriptive Statistics And Univariate Analysis}

Table 2 (Panel A) presents means, medians, and results of Wilcoxon and Median tests. Since data do not conform to assumed normal distribution, we use Wilcoxon sign rank test and Median nonparametric test to evaluate differences of mean and median between fraud and non-fraud firms in independent variables. Results show significant $(p<.05)$ difference in most variables.

TABLE 2: Descriptive Statistics for Risk Factors from the fraud triangle

\begin{tabular}{|c|c|c|c|c|c|}
\hline \multicolumn{3}{|c|}{ Risk Factors from the fraud triangle } & $\begin{array}{c}\text { Fraud } \\
(\mathbf{N}=97)\end{array}$ & $\begin{array}{c}\text { Non-fraud } \\
(\mathrm{N}=467)\end{array}$ & $\begin{array}{c}\underline{Z \text { Value }} \\
\text { Wilcoxon Test } \\
\text { Median Test }\end{array}$ \\
\hline \multicolumn{6}{|c|}{ Pressure/Incentive } \\
\hline \multirow{10}{*}{$\mathrm{H} 1$} & \multirow{2}{*}{$H I G H G R$} & Mean & 0.2800 & 0.4300 & $-2.7740 * * *$ \\
\hline & & Median & 0.0000 & 0.000 & $-2.7744 * * *$ \\
\hline & \multirow{2}{*}{$A F E$} & Mean & 3.9909 & 0.6143 & $4.4185^{* * *}$ \\
\hline & & Median & 0.9600 & 0.3121 & $3.0244 * * *$ \\
\hline & \multirow{2}{*}{ LOSS } & Mean & 0.2300 & 0.0071 & $4.7172 * * *$ \\
\hline & & Median & 0.0000 & 0.0000 & $4.7127 * * *$ \\
\hline & \multirow{2}{*}{$N C F O$} & Mean & 0.2500 & 0.1100 & $3.5677 * * *$ \\
\hline & & Median & 0.0000 & 0.0000 & $3.5638 * * *$ \\
\hline & \multirow{2}{*}{$L E V$} & Present & 0.6841 & 0.3973 & $9.0375 * * *$ \\
\hline & & Percent & 0.6019 & 0.4042 & $6.8005 * * *$ \\
\hline \multirow{2}{*}{$\mathrm{H} 2$} & \multirow{2}{*}{$P L E D G E$} & Mean & 0.3860 & 0.2052 & $4.5284 * * *$ \\
\hline & & Median & 0.3005 & 0.0977 & $3.2330 * * *$ \\
\hline \multicolumn{6}{|c|}{ Opportunity } \\
\hline \multirow{4}{*}{ H3 } & \multirow{2}{*}{$I N V \%$} & Mean & 0.6513 & 0.3650 & $1.5971 *$ \\
\hline & & Median & 0.3951 & 0.2996 & $2.1182 * *$ \\
\hline & \multirow{2}{*}{$R P T \%$} & Mean & 0.1816 & 0.1285 & $1.7757 * *$ \\
\hline & & Median & 0.0700 & 0.0400 & $1.8710 * *$ \\
\hline \multirow{6}{*}{$\mathrm{H} 4$} & \multirow{2}{*}{$C E O$} & Mean & 0.2900 & 0.2400 & 0.9650 \\
\hline & & Median & 0.0000 & 0.0000 & 0.9655 \\
\hline & \multirow{2}{*}{$D E V R$} & Mean & 0.8300 & 0.8100 & $1.5327 *$ \\
\hline & & Median & 0.9800 & 0.9300 & $1.8952 * *$ \\
\hline & \multirow{2}{*}{$\triangle I N A U D$} & Mean & 0.1600 & 0.0685 & $2.8672 * * *$ \\
\hline & & Median & 0.0000 & 0.0000 & $2.8777 * * *$ \\
\hline \multicolumn{6}{|c|}{ Attitude/Rationalization } \\
\hline \multirow{2}{*}{$\mathrm{H} 5$} & \multirow{2}{*}{$R S T$} & Mean & 1.1900 & 0.2000 & $5.1749 * * *$ \\
\hline & & Median & 0.0000 & 0.0000 & $4.7504 * * *$ \\
\hline & \multirow{2}{*}{$\triangle C P A$} & Mean & 0.1900 & 0.0150 & $7.1152 * * *$ \\
\hline & & Median & 0.0000 & 0.0000 & $7.1096 * * *$ \\
\hline \multicolumn{6}{|c|}{ Control Variable } \\
\hline \multirow{2}{*}{\multicolumn{2}{|c|}{ SIZE }} & Mean & 9.8062 & 9.7982 & 0.3078 \\
\hline & & Median & 9.7890 & 9.8093 & -0.1115 \\
\hline
\end{tabular}

\footnotetext{
$*, * *, * * *$ Significant at $p$-value $<.10, .05, .01$, respectively.
} 
FRAUD $\quad=1$ for firms subject to financial restatements mandated by TSFB or categorized by TSFIPC as cases of fraudulent financial reporting, otherwise 0 .

HIGHGR = dummy variable coded by 1 for growth rate on assets of a firm greater than that of industry median, and coded by 0 otherwise.

AFE = value obtained by subtraction of company's realized earnings per share after restatement from the latest analysts' earnings forecasts of earnings per share in event year.

LOSS = dummy variable with value of 1 if firms report losses in the first and second years before the event years; otherwise 0 .

$\mathrm{NCFO} \quad=$ dummy variable with value of 1 if firms report negative cash flow from operating activity in the first and second years before the event years; otherwise 0 .

$L E V \quad=$ total liability to total assets after restatement.

PLEDGE = value of the percentage of shareholdings pledged for loans and credits by directors and supervisors report to Taiwan Securities and Futures Commission (TSFC).

$I N V \%=$ total equity investment to total stockholder equity.

$R P T \%=$ sales about related party transaction scaled by total sales.

CEO = dummy variable with a value of 1 if chairperson of board holds managerial position of CEO or president; otherwise 0 .

$\triangle I N A U D=$ number of internal auditor switch in the past three years (including the event year).

$D E V R \quad=$ controlling shareholders' cash flow rights to control rights.

$R S T \quad=$ number of earnings-affected restatements in two years before fraud occurrence.

$\triangle C P A=$ number of auditor switch in the fraud year.

SIZE $\quad=$ logarithm of a firm's total assets after financial restatement.

The pressure/incentive variables $A F E, L O S S, N C F O$, and $L E V$ show positive significance $(p<.01)$ of conformity with H1. Probability of fraud rises if a firm contains large analyst's forecast error, reports losses over two successive years, reports negative cash flow from operation over two successive years, or contains high leverage ratios. HIGHGR does not conform to prediction sign, although the valuable is significant $(p<.01)$. After rechecking original data, we find that non-fraud firms possess high rate of growth and can be free from growth trap. Directors' and supervisors' pledging stock rate (PLEDGE) is significant at $p$ level of .01, attesting that an increase in $P L E D G E$ of a firm raises fraud probability. Among opportunity variables, equity investment ratio (INV\%) and percentage of sales about related party transaction $(R P T \%)$ of fraud firms are significant, supporting $\mathrm{H} 3$ that a firm with higher ratio of complex transactions accompanies higher probability of fraud. Deviation in cash flow away from the control rights $(D E V R)$ is positively related to fraud occurrence (significant at $p<.1$ ), indicating opposite expectations. $C E O$ is insignificant. The rationale behind this result is that the listed firms are mainly family controlled in Taiwan and a firm's chairman of the board is usually its president. However, CEO is crucial to risk factor in prior research (Beasley, 1996; Beasley et al., 1999, Abbott et al., 2000). Note that, firms in the US are typically run by professional managers. Results of $\triangle I N A U D$ by Wilcoxon and Median tests support $\mathrm{H} 4$, attesting that the internal audit function is efficiently enforced by stable internal audit management. When internal auditor frequently switches, it is possible that internal control system becomes weak to prevent fraud occurrence. All attitude/rationalization variables for fraud and non-fraud firms are significant $(p<.01)$. A firm with higher frequency of financial restatement in two years before fraud occurrence causes lower reliability of financial statement, more queries about manager's integrity, supporting H5. The relation between manager and auditor exhibits rationalizations of managerial organization. Higher turnover frequency of auditor in the event year $(\triangle C P A)$ indicates higher fraud risk, supporting H6. However, $S I Z E$ is insignificant under appropriate control on matching samples, indicating fraud and non-fraud firms in the samples are of approximate scale in total assets.

\section{Correlation Coefficient Analysis And Modeling}

Table 3 presents the correlation matrix for dependent and independent variables. As expected, most independent variables are significantly related to fraud. All coefficients among other independent variables are below .25, except the correlation coefficient between $L E V$ and LOSS and that between $L E V$ and NCFO. Although, $H I G H G R$ is significantly related to fraud, its sign is opposite to prediction. After univariable analyses by Wilcoxont, Median, and Spearman-rank correlation tests, we follow recommendations of Hosmer and Lemeshow (2000) to 
select explanatory variables having a $p$-value equal or smaller than 0.15 in univariate analyses. Among the five H1 variables, $L E V$ is significantly correlated to $L O S S$ and NCFO. To avoid multicollinearity problem, the three variables are represented by $L E V$. The relationship between $I N V \%$ and $R P T \%$ is statistically significant. Since the model's increasable explanation is feeble by $I N V \%$, we choose $R P T \%$ as a proxy variable for the percentage of complex transactions. Finally, we select three pressure/incentive variables, two opportunity variables, and two attitude/rationalization variables for the six hypotheses containing thirteen variables. The logistic model is written:

$F R A U D=\beta_{0}+\beta_{1} A F E+\beta_{2} L E V+\beta_{3} P L E D G E+\beta_{4} R P T \%+\beta_{5} \triangle I N A U D+\beta_{6} R S T+\beta_{7} \triangle C P A+\beta_{8} S I Z E+\varepsilon$

where:

FRAUD $=1$ for firms subject to financial restatements mandated by TSFB or categorized by TSFIPC as cases of fraudulent financial reporting, otherwise 0 .

AFE = value obtained by subtraction of company's realized earnings per share after restatement from the latest analysts' earnings forecasts of earnings per share in event year.

$L E V \quad=$ total liability to total assets after restatement.

PLEDGE = value of the percentage of shareholdings pledged for loans and credits by directors and supervisors report to Taiwan Securities and Futures Commission (TSFC).

$R P T \% \quad=$ sales about related party transaction scaled by total sales.

$\triangle I N A U D=$ number of internal auditor switch in the past three years (including the event year).

$R S T \quad=$ number of earnings-affected restatements in two years before fraud occurrence.

$\triangle C P A \quad=$ number of auditor switch in the fraud year.

SIZE $\quad=$ logarithm of a firm's total assets after financial restatement.

Besides correlation analysis, we check the tolerance and variance inflation factor (VIF) of independent variables. Values of tolerance of all independent variables are greater than 0.75 , far exceeding the requirement of 0.2 (Menard, 1995). Values of VIF of all independent variables are below 10 (Neter et al., 1990), not exceeding 1.5 (Greene, 1999). No multicollinearity problem exists in the present model.

\section{Multivariate Results}

\section{Logistic Regression Model}

Next, we test three parts of fraud triangle by logistic regression. Table 4 presents estimations of parameters, Wald chi-square, $p$-value, and goodness-of-fit statistics for the logistic regression model. Three pressure/incentive variables, $A F E, L E V$, and PLEDGE, of Model 1 are significantly correlated to FRAUD. Two opportunity variables, $R P T \%$ and $\triangle I N A U D$, of Model 2 are significantly correlated to FRAUD. Two attitude/rationalization variables, RST, $\triangle C P A$, of Model 3 are significantly correlated to FRAUD. Statistically significant likelihood ratios of the three models are $142.0395(p<.0001), 10.8014(p<.05)$, and $72.1030(p<.0001)$, respectively. Class percent concordances of the three models are $80.8 \%, 58.7 \%$, and $86.5 \%$, respectively. Model 4 consists of three pressure/incentive variables, two opportunity variables, two attitude/rationalization variables, and one control variable. Likelihood ratio of Model 4 is highly significant $(p<.0001)$. Class percent concordance and R-square of Model 4 are, respectively, $86.5 \%$ and 0.2813 . Note that R-square is greater than the requirement of 0.2 (McFadden, 1974). These results display our model's adequacy. Six variables of Model 4, i.e., AFE, LEV, PLEDGE, RPT\%, RST, and $\triangle C P A$, are significantly positively correlated to probability of fraud. Multivariable results indicate that a firm sustaining financial pressure ( $A F E$ and $L E V$ in $\mathrm{H} 1$ ), supervisor/director sustaining financial pressure connected with firm's earnings (PLEDGE in H2), high percentage of complex transactions (RPT\% in H3), questionable managerial integrity ( $R S T$ in H5), and deteriorated relation between a firm and its auditor ( $\triangle C P A$ in H6) are positively correlated to fraudulent statements reporting. The results also provide new evidence to support H1, H2, H3, H5, and H6. As far as $\mathrm{H} 4$ is concerned, it is supported by results of univariable tests and Model 2. As expected, SIZE is significantly negatively correlated to financial fraud, as attested in prior papers (Bonner et al. 1998; Beasley et al. 1999). When a firm of larger size possesses stronger internal control systems, probability of fraud becomes lower. 
TABLE 3: Correlation matrix for dependent and independent variables ${ }^{\mathrm{a}, \mathrm{b}}$

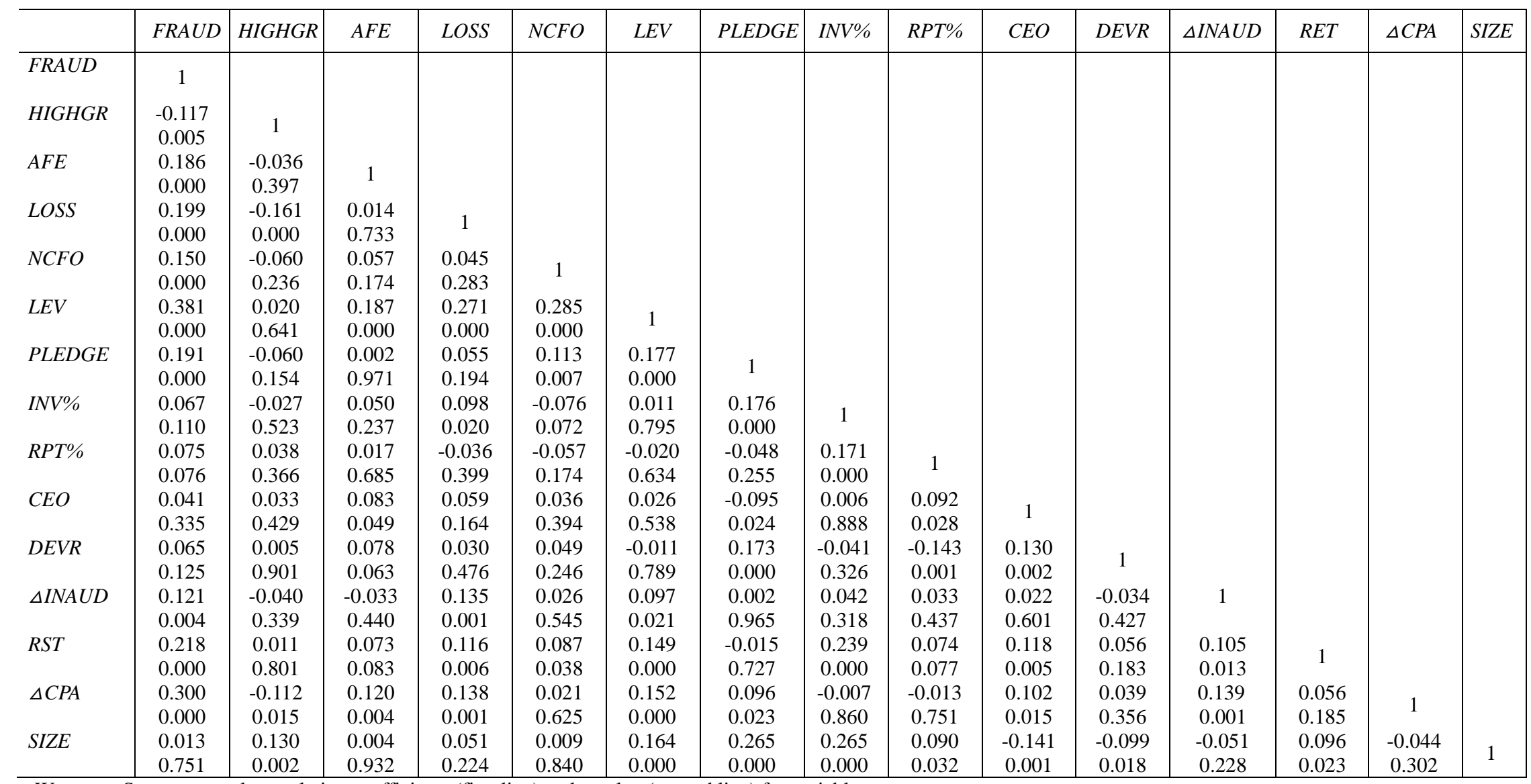

a. We report Spearman-rank correlation coefficients (first line) and $p$ value (second line) for variables.

b. Variables are defined in Table 2. 
TABLE 4: Results of Models

\begin{tabular}{|c|c|c|c|c|c|c|c|c|c|}
\hline \multicolumn{10}{|c|}{ Fraud $=\beta_{0}+\beta_{1} A F E+\beta_{2} L E V+\beta_{3} P L E D G E+\beta_{4} R P T \%+\beta_{5} \Delta I N A U D+\beta_{6} R S T+\beta_{7} \triangle C P A+\beta_{8} S I Z E+\varepsilon$} \\
\hline \multirow[b]{2}{*}{ Variable } & \multirow{2}{*}{$\begin{array}{l}\text { Exp. } \\
\text { Sign }\end{array}$} & \multicolumn{2}{|c|}{ Model 1} & \multicolumn{2}{|c|}{ Model 2} & \multicolumn{2}{|c|}{ Model 3} & \multicolumn{2}{|c|}{ Model 4} \\
\hline & & Coe. $^{\mathrm{a}}$ & Wald $\chi^{2}$ & Coe. $^{\mathrm{a}}$ & Wald $\chi^{2}$ & Coe. $^{\mathrm{a}}$ & Wald $\chi^{2}$ & Coe. $^{\mathrm{a}}$ & Wald $\chi^{2}$ \\
\hline Intercept & & -0.4485 & 0.0166 & -2.7320 & 0.9741 & -0.5789 & 0.0352 & 1.3761 & 0.1278 \\
\hline \multicolumn{10}{|c|}{ Pressure/Incentive } \\
\hline$A F E$ & + & 0.1677 & $9.9298^{* * *}$ & & & & & 0.1942 & $12.4439^{* * *}$ \\
\hline$L E V$ & + & 5.4916 & $42.0024^{* * *}$ & & & & & 4.5770 & $24.0543^{* * *}$ \\
\hline PLEDGE & + & 1.4334 & $10.0702^{* * *}$ & & & & & 1.8127 & $13.2082^{* * *}$ \\
\hline \multicolumn{10}{|l|}{ Opportunity } \\
\hline$R P T \%$ & + & & & 1.1245 & $5.2455^{* *}$ & & & 1.5059 & $4.7253^{* *}$ \\
\hline$\triangle I N A U D$ & + & & & 0.7032 & $6.2225^{* *}$ & & & 0.4153 & 1.2744 \\
\hline \multicolumn{10}{|c|}{ Attitude/Rationalization } \\
\hline$R S T$ & + & & & & & 0.5446 & $20.8184^{* * *}$ & 0.5243 & $16.0400^{* * *}$ \\
\hline$\triangle C P A$ & + & & & & & 2.5472 & $28.4351^{* * *}$ & 2.1502 & $12.3446^{* * * *}$ \\
\hline \multicolumn{10}{|c|}{ Control Variable } \\
\hline SIZE & - & -0.4573 & 1.6279 & 0.0930 & 0.1090 & -0.1458 & 0.2133 & -0.6762 & $2.8646^{*}$ \\
\hline LR index & & 142.0395 & $<.0001)$ & 10.8014 & (.05) & 72.103 & $<.0001)$ & 186.3288 & $.0001)$ \\
\hline Model $\mathrm{R}^{2}$ & & & 2226 & & 19 & & 1200 & & 813 \\
\hline Concordant & & & $0.8 \%$ & & $7 \%$ & & $.2 \%$ & & $5 \%$ \\
\hline Discordant & & & $8.8 \%$ & & $2 \%$ & & $.7 \%$ & & $1 \%$ \\
\hline
\end{tabular}

a. The coefficient of estimated of the model.

$*, * *, * * *$ Significant at $p$-value $<.10, .05, .01$, respectively.

The variables are defined in Table 2.

\section{Assessments Of Model Performance}

We can confirm assessments of model performance with limited acknowledgement of fraud samples by the jackknife method, which appraises result replicability without reconducting the same study with new samples (Crask and Perreault, 1977; Tukey, 1958). The jackknife method is applied by removal of one observation and repeat of the rule by $n$ times ( $n$ equals number of samples) to determine misclassified frequency. Thus, the jackknife method is called the "leave-one-out" method. This approach was demonstrated to produce more conservative and fewer biased estimates of true population chacteristics (Crask and Perreault, 1977).

Table 5 presents classification accuracy of Model 4 using the Jackknife method by cut-off points from 0.00 to 1.00 with 0.05 intervals. Under different cut-off point, 564 firms, divided into fraud and non-fraud firms by Model 4, reveal different classification accuracy. To maximize total percentage of classification accuracy for both groups, the cut-off point is approximate 0.15. At probabiliy level of 0.10, 80 fraud firms out of 97 fraud firms are correctly classified with accuracy of $82.5 \%$, and 327 non-fraud firms out of 467 non-fraud firms are correctly classified with accuracy of $70 \%$. 
TABLE 5: Classification Table by Jackknife Method

\begin{tabular}{|c|c|c|c|c|}
\hline \multirow{2}{*}{ Probability level } & \multicolumn{2}{|c|}{ Fraud } & \multicolumn{2}{|c|}{ Non-fraud } \\
\hline & Correct & $\%$ & Correct & $\%$ \\
\hline 1.00 & 0 & 0.00 & 467 & 100.00 \\
\hline 0.99 & 12 & 12.40 & 467 & 100.00 \\
\hline 0.98 & 13 & 13.40 & 467 & 100.00 \\
\hline 0.97 & 15 & 15.50 & 466 & 99.80 \\
\hline 0.96 & 17 & 17.50 & 466 & 99.80 \\
\hline 0.95 & 17 & 17.50 & 466 & 99.80 \\
\hline 0.90 & 21 & 21.60 & 465 & 99.60 \\
\hline 0.85 & 24 & 24.70 & 465 & 99.60 \\
\hline 0.80 & 26 & 26.80 & 463 & 99.10 \\
\hline 0.75 & 31 & 32.00 & 462 & 98.90 \\
\hline 0.70 & 32 & 33.00 & 458 & 98.10 \\
\hline 0.65 & 39 & 40.20 & 457 & 97.90 \\
\hline 0.60 & 39 & 40.20 & 456 & 97.60 \\
\hline 0.55 & 41 & 42.30 & 454 & 97.20 \\
\hline 0.50 & 44 & 45.40 & 453 & 97.00 \\
\hline 0.45 & 46 & 47.40 & 452 & 96.80 \\
\hline 0.40 & 50 & 51.50 & 450 & 96.40 \\
\hline 0.35 & 53 & 54.60 & 445 & 95.30 \\
\hline 0.30 & 55 & 56.70 & 437 & 93.60 \\
\hline 0.25 & 59 & 60.80 & 425 & 91.00 \\
\hline 0.20 & 68 & 70.10 & 410 & 87.80 \\
\hline 0.15 & 74 & 76.30 & 385 & 82.40 \\
\hline 0.10 & 80 & 82.50 & 327 & 70.00 \\
\hline 0.09 & 80 & 82.50 & 313 & 67.00 \\
\hline 0.08 & 80 & 82.50 & 280 & 60.00 \\
\hline 0.07 & 83 & 85.60 & 252 & 54.00 \\
\hline 0.06 & 89 & 91.80 & 227 & 48.60 \\
\hline 0.05 & 90 & 92.80 & 186 & 39.80 \\
\hline 0.04 & 92 & 94.80 & 129 & 27.60 \\
\hline 0.03 & 94 & 96.90 & 79 & 16.90 \\
\hline 0.02 & 96 & 99.00 & 41 & 8.80 \\
\hline 0.01 & 97 & 100.00 & 5 & 1.10 \\
\hline 0.00 & 97 & 100.00 & 0 & 0.00 \\
\hline
\end{tabular}

TABLE 6: Risk Classification Table

\begin{tabular}{lcc}
\hline \multicolumn{1}{c}{ Hazard rate } & Fraud & Non-fraud \\
\hline Low risk group $(<0.05)$ & $6(6.2 \%)$ & $125(26.9 \%)$ \\
Middle risk group $(0.05-0.10)$ & $13(13.4 \%)$ & $187(40.0 \%)$ \\
High risk group $(0.10-0.20)$ & $17(17.5 \%)$ & $95(20.3 \%)$ \\
Very high risk group $(>0.20)$ & $61(62.9 \%)$ & $60(12.8 \%)$ \\
\hline Total & $97(100.0 \%)$ & $467(100.0 \%)$ \\
\hline
\end{tabular}

564 firms are divided into "low risk", "middle risk", "high risk", and "very high risk" groups according to hazard rate in Table 6. Hazard rate greater than 0.20 of a firm belongs to the very high risk group, in which $62.9 \%$ of fraud firms are correctly classified. Hazard rate smaller than 0.05 of a firm belongs to the low risk group, in which $26.9 \%$ non-fraud firms are correctly classified. If we combine the very high group with the high risk group, classification accuracy of fraud firms is $80.4 \%$. By combination of the low risk group with the middle risk group, classification accuracy of non-fraud firms is $66.9 \%$. Classification accuracy of the logistic model for non-fraud firms is lower than fraud firms, exhibiting higher type I error of the logistic model (Tam and Kiang, 1992). In current audit environment, fail to detect existing fraud seems to be more concerned than costly examination of a nonexistent fraud (Wilks and Zimbelman, 2004). Next, we evaluate the model by additional test. 
TABLE 7: Results of Logistic Regression ${ }^{\text {a }}$

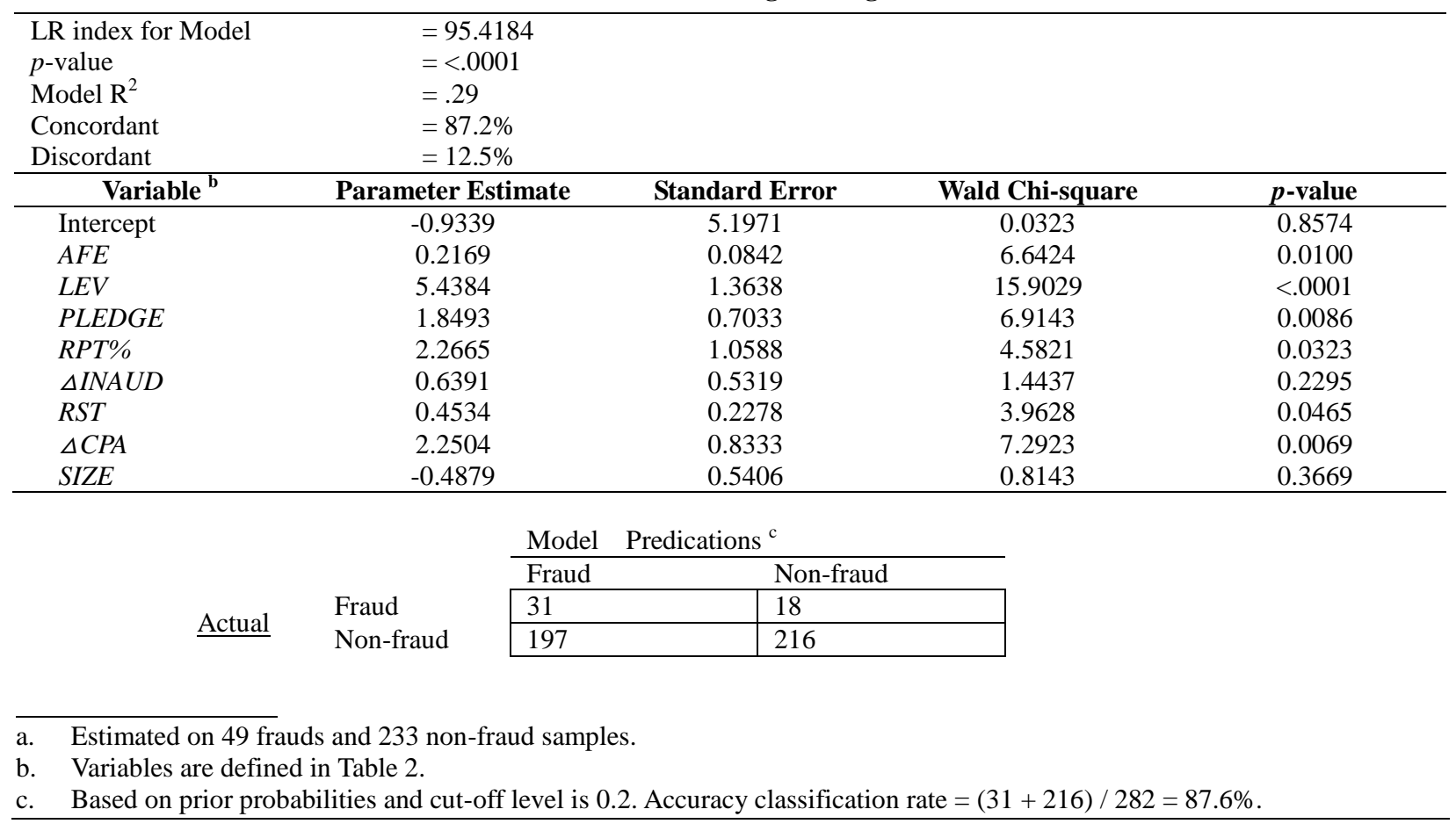

\section{Additional Test}

To test stability of the model, original samples are randomly divided into two groups, estimated samples (49 fraud samples and 233 non-fraud samples) and holdout samples (48 fraud samples and 234 non-fraud samples). Results of logistic regression of estimated examples are listed in Table 7. Likelihood ratio, class percent concordance, and R-square are, respectively, $95.4184(p<.0001), 87.2 \%$, and 0.29, similar to Model 4. Based on prior probability and cut-off level of 0.2 , rate of accuracy classification is $87.6 \%$. However, SIZE is insignificant.

FIGURE 1

Percent of Fraud and Non-fraud Cases within Risk Categories

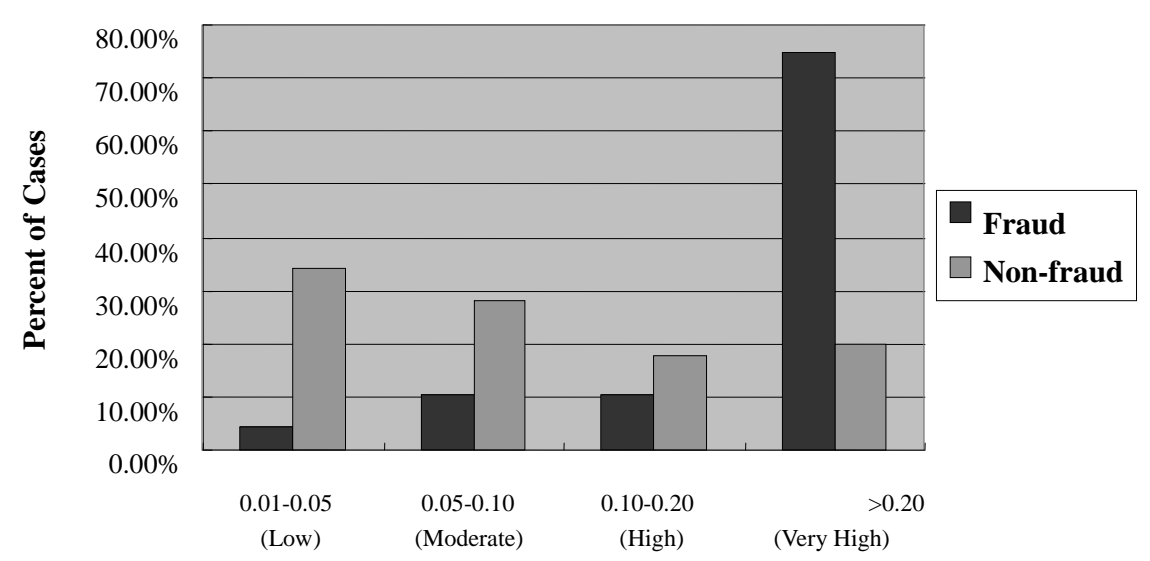

Risk Category 
To examine effect of size and diversity of samples on Model 4, we use the model $(F R A U D=-0.9339+$ $0.2169 A F E+5.4384 L E V+1.8393 P L E D G E+2.2665 R P T \%+0.6391 \triangle I N A U D+0.4534 R S T+2.2504 \Delta C P A-$ 0.4879 SIZE) assayed by estimated samples to classify holdout samples according to hazard rate into "very high risk", "high risk", "middle risk", and "low risk" groups. Figure 1 exhibits classification accuracy of holdout samples. This results imply that the percentage of fraud firms correctly classified into the very high risk and the high risk groups is $85.4 \%(75 \%+10.4 \%)$ and that of non-fraud firms correctly classified into the low risk and the middle risk groups is $62.4 \%(34.2 \%+28.2 \%)$. These results affirm fine classification ability of the present proposed model.

\section{CONCLUSIONS}

This research examines risk factors of the fraud triangle, which becomes the core of all fraud auditing standards, to assess the likelihood of fraudulent financial reporting. 97 fraud and 467 non-fraud cases are used to develop and test a logistic regression model that estimates the likelihood of fraudulent financial reporting. Significant proxy variables include analyst's forecast error $(A F E)$, debt ratio $(L E V)$, directors and supervisors' stock pledged ratio (PLEDGE), percentage of sales related party transaction (RPT\%), historical restate times (RST), and number of auditor switch $(\triangle C P A)$, belonging pressure/incentive, opportunity, and attitude/rationalization. Results indicate that such fraudulent financial reporting is positively correlated to one of the following conditions: more financial pressure of a firm or a supervisor of a firm, higher ratio of complex transactions, more questionable integrity of firm managers, or more deterioration in relation between a firm and its auditor. Firm size negatively correlates with fraud, consistent with previous papers (Bonner et al. 1998; Beasley et al. 1999). To assess model performance, we apply jackknife method in forecasting classification accuracy. Rate of correct classification in the present model is 86.5\%, higher than models developed by Persons (1995), Kaminski et al. (2004), and Skousen and Wright (2006). Through addition test, the model in this paper presents good classification ability. As compared with prior researches, this paper is superior in contributions to this field in two ways. First, based on fraud triangle accepted by fraud standards (SAS 99, ISA 240, and TSAS 43), we develop a practical model. Second, instead of subjective measures and copious red flag questionnaires, we identify proxy variables related to pressure/incentive, opportunity, and attitude/rationalization. Results suggest that a simple logistic model constructed from examples of fraud-risk factors of ISA 240 and SAS 99 is able to assess the likelihood of fraudulent financial reporting and can become a useful tool for practitioners.

\section{REFERENCES}

1. Abbott, L., Y. Park, and S. Parker, "The Effects of audit committee activity and independence on corporate fraud," Managerial Finance, 26(11), 55-67, 2000.

2. Albrecht, W. S., and M. B. Romney, "Red-Flagging Management Fraud: A Validation," Advances in Accounting, 3, 323-334, 1986.

3. Anthony, J. H., and K. Ramesh, "Association between Accounting Performance Measures and Stock Prices," Journal of Accounting and Economics, 15(2-3), 203-227, 1992.

4. Asare, S. K., and A. M. Wright, "The Effectiveness of Alternative Risk Assessment and Program Planning Tools in a Fraud Setting," Contemporary Accounting Research, 21(2), 325-352, 2004.

5. Apostolou, B., J. Hassell, S. Webber, and G. Sumners, "The Relative Importance of Management Fraud Risk Factors," Behavioral Research in Accounting, 13, 1-24, 2001.

6. Barth, M. E., J. A. Elliot, and M. W. Finn, "Market Rewards Associated with Patterns of Increasing Earnings," Journal of Accounting Research, 37(2), 387-413, 1999.

7. Beasley, M., "An Empirical Analysis of the Relation between the Board of Director Composition and Financial Statement Fraud," The Accounting Review, 71(4), 443-465, 1996.

8. Beasley, M. S., J. V. Carcello, and D. R. Hermanson, Fraudulent Financial Reporting: 1987-1997 An Analysis of U. S. Public Companies, Committee of Sponsoring Organizations of the Treadway Commission. Jersey City, NJ: AICPA, 1999.

9. Beasley, M. S., J. V. Carcell, D. R. Hermanson, and P. D. Lapides, "Fraudulent Financial Reporting: Consideration of Industry Traits and Corporate Governance Mechanisms," Accounting Horizons, 14(4), 441-454, 2000. 
10. Beatty, A., and J. Webber, "The Effects of Debt Contracting on Voluntary Accounting Methods Change," The Accounting Review, 78(1), 119-142, 2003.

11. Becker, C. L., M. L. Defond, J. Jiarnbalvo, and K. R. Subramanyarn, "The Effect of Audit Quality on Earnings Management," Contemporary Accounting Research, 15(1), 1-24, 1998.

12. Bell, T. B., and J. V. Carcello, "A Decision Aid for Assessing the Likelihood of Fraudulent Financial Reporting," Auditing: A Journal of Practice \& Theory, 19(1), 169-184, 2000.

13. Bell, T. B., S. Szykowny, and J. J. Willingham, "Assessing the Likelihood of Fraudulent Reporting: A Cascaded Logic Aproach. Working Paper, KPMG Peat Marwick, 1991.

14. Bhattacharya, U., H. Daouk, and M. Welker, "The World Price of Earnings Opacity," The Accounting Review, 78 (3), 641-678, 2003.

15. Black, E. L., "Life-Cycle Impacts on the Incremental Value-Relevance of Earnings and Cash Flow Measures," The Journal of Financial Statement Analysis, 4(1), 40-56, 1998.

16. Bolcher, E., and J. C. Cooper, “A Study of Auditors' Analytical Review Performance," Auditing: A Journal of Practice and Theory, 7 (2), 1-28, 1988.

17. Bolcher, E., The Role of Analytical Procedures in Detecting Management Fraud, Institute of Management Accountants, Montvale, NJ, 1992.

18. Bonner, S. E., Z-V. Palmrose, and S. M. Young, "Fraud Type and Auditor Litigation: An Analysis of SEC Accounting and Auditing Enforcement Releases," The Accounting Review, 73(4), 503-532, 1998.

19. Bratton, W., "Enron and the Dark Side of Shareholder Value," Tulane Law Review, 76, 1275-1361, 2002.

20. Calderon, T. G. and B. P. Green, "Analysts' Forecasts as an Exogenous Risk Indicator in Analytical Auditing," Advances in Accounting, 12, 281-300, 1994.

21. Chen, K. Y. and S. Y. Wu, "Industry Specialists, Audit Fees and Auditor Size: Evidence from Taiwan," Taiwan Accounting Review, 5(1), 41-69, 2004.

22. Claessens, S., S. Djankov, and L. H. P. Lang, "The Separation of Ownership and Control in East Asian Corporation," Journal of Financial Economics, 58(1-2), 81-112, 2000.

23. Collins, D. W., M. Pincus, and H. Xie. "Equity Valuation and Negative Earnings: The Role of Book Value of Equity," The Accounting Review, 74, 29-61, 1999.

24. Cottrell, D. M., and W. S. Albrecht, "Recognizing the Symptoms of Employee Fraud," Health Care Financial Management, May, 19-25, 1994.

25. Crask, M. R., W. D. Jr. Perreault, "Validation of Discriminant Analysis in Marketing Research," Journal of Marketing Research, 14(1), 60-68, 1977.

26. Craswell, A. T., J. R. Francis, and S. L. Taylor, “Auditor Brand Name Reputations and Industry Specializations," Journal of Accounting and Economics, 20(2-3), 297-322, 1995.

27. Cressey, D. R., Other People's Money: A Study in the Social Psychology of Embezzlement, Glencoe, IL: Free Press, 1953.

28. Deakin, S., and S. J. Konzelmann, "Learning from Enron," Corporate Governance - An International Review, 12(2), 134-142, 2004.

29. DeAngelo, L. E., “Auditor Size and Auditor Quality,” Journal of Accounting and Economics, 3(3), 183-199, 1981.

30. Dechow, P. M., R. G. Sloan, and A. P. Sweeney, "Causes and Consequences of Earnings Manipulation: An Analysis of Firms Subject Enforcement Actions by the SEC," Contemporary Accounting Research, 13(1), 1-36, 1996.

31. Degeorge, F., J. Patel, and R. Zeckhauser, "Earnings Management to Exceed Thresholds," Journal of Business, 72(1), 1-33, 1999.

32. Duke, J. C., and H. C. Hunt III, "An Empirical Examination of Debt Covenant Restrictions and Accounting-Related Debt Proxies," Journal of Accounting \& Economics, 12(1-3): 45-63, 1990.

33. Eining, M., D. Jones, and J. Loebbecke, "Reliance on Decision Aids: An Examination of Auditors' Assessment of Management Fraud," Auditing: A Journal of Practice and Theory, 16(2), 1-19, 1997.

34. General Accounting Office, Financial Statement Restatements: Trends, Market Impacts, Regulatory Responses, and Remaining Challenges. GAO-03-138, 2002.

35. Greene, W., Econometric Analysis, Macmillan, New York, 1999. 
36. Hansen, J. V., J. B. McDonald, W. F. Messier, Jr., and T. B. Bell, “A Generalized Qualitative-Response Model and the Analysis of Management Fraud," Management Science, 42, 1022-1032, 1996.

37. Hayn, C., "The Information Content of Losses," Journal of Accounting and Economics, 20(2), 125-153, 1995.

38. Heiman-Hoffman, V. B., K. P. Morgan, and J. M. Patton, "The Warning Signs of Fraudulent Financial Reporting," Journal of Accountancy, 182(4), 75-81, 1996.

39. Hogan, C. E., and D. C. Jeter, "Industry Specialization by Auditors," Auditing: A Journal of Practice and Theory, 18(1), 1-17, 1999.

40. Hosmer, D. W., and S. Lemeshow, Applied Logistic Regression, Second edition, New York, NY: John Wiley and Sons, Inc., 2000.

41. Jensen, M. C., "The Modern Industrial Revolution, Exit, and the Failure of Internal Control Systems," Journal of Finance, 48(3), 831-880, 1993.

42. Kaminski, K., T. Wetzel, and L. Guan, "Can Financial Ratios Detect Fraudulent Financial Reporting?" Managerial Auditing Journal, 19(1), 15-28, 2004.

43. Kasznik, R., and M. F. McNichols, "Does Meeting Expectations Matter? Evidence from Analyst Forecast Revisions and Share Prices," Journal of Accounting Research, 40(3), 727-759, 2002.

44. Krishnan, J., and J. Krishnan, "Litigation Risk and Auditor Resignations," The Accounting Review, 72(4), 539-560, 1997.

45. Krishnan, J., “Audit Committee Quality and Internal Control: An Empirical Analysis,” The Accounting Review, 20(5), 649-675, 2005.

46. La Porta, R., F. Lopez-de-Silanes, and A. Shleifer, "Corporate Ownership around the World," Journal of Finance, 54(2), 471-517, 1999.

47. La Porta, R., F. Lopez-de-Silanes, A. Shleifer, and R. W. Vishny, "Investor Protection and Corporate Valuation," Journal of Finance, 57(3), 1147-1171, 2002.

48. Lee, T. S. and Y. H. Yeh, "Corporate Governance and Financial Distress: Evidence from Taiwan," Corporate Governance - An International Review, 12(3), 378-388, 2004.

49. Lipe, R. C., L. Bryant, and S. K. Widener, "Do Nonlinearity, Firm-Specific Coefficients, and Losses Represent Distinct Factors in the Relation between Stock Returns and Accounting Earnings?" Journal of Accounting and Economics, 25(2),195-214, 1998.

50. Loebbecke, J. K., M. M. Eining, and J. J. Willingham, “Auditors' Experience with Material Irregularities: Frequency, Nature, and Detectability," Auditing: A Journal of Practice \& Theory, 9(1), 1-28, 1989.

51. Lopez, T. J., L. Rees, "The Effect of Beating and Missing Analysts' Forecasts on the Information Content of Unexpected Earnings," Journal of Accounting, Auditing, and Finance, 17(2), 155-184, 2002.

52. Mayhew, B. W. and M. S. Wilkins, "Audit Firm Industry Specialization as a Differentiation Strategy: Evidence from Fees Charged to Firms Going Public," Auditing: A Journal of Practice and Theory, 22(2), 33-52, 2003.

53. McFadden, D., Conditional Logit Analysis of Qualitative Choice Behavior, in Zarembka P. (ed), Frontiers in Econometrics, Academic Press, New York, pp. 105-142, 1974.

54. Menard, S., Applied Logistic Regression Analysis, Thousand Oaks, CA: SAGE Publications, Inc., 1995.

55. Moyes, G.D. and I. Hasan, “An Empirical Analysis of Fraud Detection Likelihood,” Managerial Auditing Journal, 11(3), 41-47, 1996.

56. Neter, J., W. Wasserman, and M. H. Kunter, Applied Linear Statistical Models, 3rd ed., Chicago: Irwin, 1990.

57. Nieschwitz, R. J., J. J. Schultz, and M. F. Zimbelman, “Empirical research on external Auditors' Detection of Financial Statement Fraud," Journal of Accounting Literature, 19, 190-246, 2000.

58. O’Reilly, V. M., P. J. McDonnell, B. N. Winograd, J. S. Gerson, and H. R. Jaenicke, eds. Montgomery's Auditing. $12^{\text {th }}$ edition. New York. NY: John Wiley \& Sons. 1998.

59. Owusu-Ansah, S., G. D. Moyes, P. B. Oyelere, and D. Hay, "An Empirical Analysis of the Likelihood of Detecting Fraud in New Zealand," Managerial Auditing Journal, 17(4), 192-204, 2002.

60. Palmrose, Z-V., V. Richardson, and S. Scholz, "Determinants of Market Reactions to Restatement Announcements," Journal of Accounting and Economics, 37(1), 59-89, 2004. 
61. Persons, O., "Using Financial Statement Data to Identify Factors Associated with Fraudulent Financial Reporting," Journal of Applied Business Research, 11(3), 38-46, 1995.

62. Pincus, K. V., "The Efficacy of a Red Flags Questionnaire for Assessing the Possibility of Fraud," Accounting, Organizations, and Society, 14 (1-2), 153-163, 1989.

63. Press, E. G., and J. B. Weintrop, "Accounting-Based Constraints in Public and Private Debt Agreements: Their Association with Leverage and Impact on Accounting Choice," Journal of Accounting and Economics, 12(1-3), 65-95, 1990.

64. Ramos, M., “Auditors' Responsibility for Fraud Detection,” Journal of Accountancy, 195(1), 28-36, 2003.

65. Shapiro, C., "Premiums for High Quality Products as Returns to Reputations," Quarterly Journal of Economics, 98(4), 659-679, 1983.

66. Shu, S., "Auditor Resignations: Clientele Effects and Legal Liability," Journal of Accounting and Economics, 29 (2), 173-205, 2000.

67. Skousen, C. J. and C. J. Wright, "Contemporaneous Risk Factors and the Prediction of Financial Statement Fraud," Working paper, University of Texas at Arlinton, 2006.

68. Sorenson, J. E., H. D. Grove, and F. H. Selto, "Detecting Management Fraud: An Empirical Approach," Symposium on Auditing Research, 5, 73-116, 1983.

69. Stice, J. D., "Using Financial and Market Information to Identify Pre-Engagement Factors Associated with Lawsuits against Auditors," The Accounting Review, 66(3): 516-533, 1991.

70. Swartz, M. and S. Watkins, Power Failure: The Inside Story of the Collapse of Enron. New York: Doubleday, 2003.

71. Tam, K. and M. Kiang, "Managerial Applications of Neural Networks: the Case of Bank Failure Predictions," Management Science, 38(7), 926-947, 1992.

72. Teoh, S. H. and T. J. Wong, "Perceived Auditor Quality and the Earnings Response Coefficient," The Accounting Review, 68 (2), 346-367, 1993.

73. Tukey, J. W., "Bias and Confidence in Not-Quite Large Samples," Annals of Mathematical Statistics, 29(2), 614, 1958.

74. Young, B., "Related-Party Transactions: Why They Matter and What Is Disclosed," The Corporate Governance Advisor, 13(4), 1-7, 2005.

75. Wilks, T. J. and M. F. Zimbelman, "Decomposition of Fraud-Risk Assessments and Auditors' Sensitivity to Fraud Cues," Contemporary Accounting Research, 21(3), 719-745, 2004.

76. Zmijewski, M. E., "Methodological Issues Related to the Estimation of Financial Distress Prediction Models," Journal of Accounting Research, 22 (Supplement), 59-82, 1984. 